\title{
Refining Healthcare in Terms of Diabetic Care: Future Area of Scope for Artificial Intelligence
}

\author{
Shivaji Pawar, Kamal Kr. Sharma
}

\begin{abstract}
Recently, the entire world is facing another noncommunicable disease known as Diabetics. Basic reasons behind this disease is not unique, but certainly may be due to an increase in economic burden, less activity, change in lifestyle, improper food intake and increase in the level of stress. This disease has its effects all over the ages in the world from child to old age people. Hence its treatment is a big challenge to the social and economic growth of every nation. Plenty of research is undergoing in this area to improve health care which requires certain modifications and validations by clinical trials. Advancement in artificial intelligence is able to provide unique solutions in the future. The basic motivation behind this paper is to study the entire innovation taking place in recent years in the area of diabetic prevention and detection. Continuous monitoring of blood glucose level by invasive and non-invasive sensor technology, diet monitoring system, activity monitoring, intelligent foot and artificial pancreas for diabetics is the major focus of this study. Also, these studies focus on complete medical healthcare solution by using artificial intelligence. This study will surely help to identify future scope in the area of diabetic and its prevention models which can act as a future of diabetic health care.
\end{abstract}

Index Terms-Artificial Intelligence, Diabetic, Healthcare, Activity monitoring, Intelligent foot, Artificial Pancreas, Sensor technology, Diet monitoring.

\section{INTRODUCTION}

In diabetic treatments, continuous monitoring of blood sugar is an essential requirement. This requires frequent hospital visits and goes through the panic procedure of blood prick. Due to workload burden and physical disability (old age and child) is not possible to monitor blood sugar levels regularly which cause poor blood sugar control and improper insulin control. Sensor technology plays a significant role in this area, which works on the concept of Biological mechanism. This biosensor uses different media for analysis like Interstitial Fluid (ISF), sweat, tears Saliva and many other [1-7]. Another basic area where Artificial intelligence can provide a unique solution is in terms of estimating diabetic patient's carbohydrate intakes monitoring. Increase in the number of diabetic patient worldwide, it is important to assess their diet more precisely [13-14]. Many types of research took place in this area with the help of mobile application. The basic reason behind the cause of diabetic is due to less activity of the human being and busy lifestyle. We can reduce the level of blood sugar by monitoring different physical activity with the help of mobile devices [8-12] Many kinds of research have taken place in this area but it is facing problem of accuracy, speed and real time data handling which can be reduced with the help of artificial intelligence algorithms. In artificial pancreas we can do a calculation of insulin intake as per requirements of glucose content in the body. With this strong relationship between insulin and glucose contents. We can develop a mathematical model with the help of artificial intelligence or closed loop control system with the help of switching PID predictive control [18-24]. Also, we can make model of nonlinear differential equations to develop artificial pancreas. Another area where immediate attention is required is the foot related disorders, including infection, skin ulceration, and gangrene which cause frequent hospitalization of a diabetic patients [15-17]. Development of intelligence foot can be better health-care for the diabetic patients. In a complete healthcare system, we can combine all the above features of diabetic healthcare together in which biosensor can monitor glucose content in the human body. Also activity monitoring, diet monitoring and foot information can be measured with the help of a mobile application. All inputs are given to the artificial intelligence which will give the exact data of the insulin intake requirement to the body. Also, it will generate the message system for any emergency taking place. This is known as the glucose-insulin model for diabetic patients or sometimes known as a virtual physician.

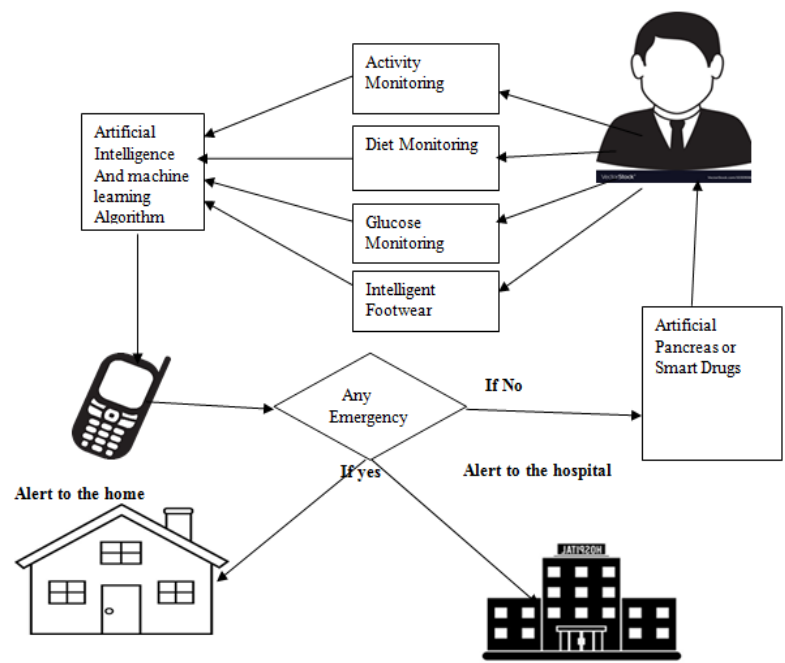

Fig.no.1 Virtual diabetic care for future development. 


\section{LITERATURE REVIEW}

For the better understanding, we have divided the literature survey into four major parts known as sensor technology, Diet control, Activity monitoring, intelligent foot and artificial pancreas.

\section{A. Recent Sensor technology for glucose monitoring}

An electrochemical wearable sensor which works on the principle of conversion of change in ions formation into electrical properties. The enzyme-based sensor provides better sensitivity and selectivity, but it consists the problem of operational stability. Glucose biosensor uses the enzyme glucose oxidase (GOx), a protein that contains the high levels of glycosylation on the molecule's surface. Stability is an important factor in this type of sensor and it is the future consideration for the research. These sensors further get classified depending upon its applications on the body. Few applications are tattoo sensor, contact lenses sensors, and patch sensor. Some sensor is also implemented in terms of clothing and textile-based applications like a smart shirt, thick film textile-based sensors, and bandage sensors. Also, we can use bio-sensors in terms of accessories like gluco watch, Pedometer, head band, arm band, wrist band, ring band, and chip sensors. Many new innovations are taking place in terms of non-invasive blood sensor by using electrostatic capacitive sensors where the property of biological tissue and blood glucose can be converted into electrical permittivity and conductivity. Due to the increase in demands of bio-sensor more efforts should be taken to increase the stability of biosensor. The biosensor will satisfy the need of diabetic patients when the biosensor consists of following properties like durable, easy to use, and higher in sensitivity and long term stability Artificial intelligence and biological sciences can come together to develop the more efficient non-invasive sensor for glucose monitoring. The biosensor is a special purpose transducer which converts biological data into an electrical signal [1-7].

Fig no. 2 shows Basic principal of Biosensor.

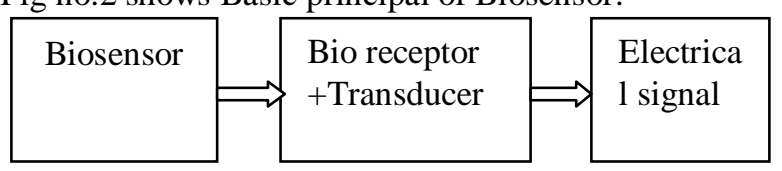

Fig.no.2

Now days proactive AI models need highly sensitive and stable invasive Biosensor to help diagnosis of cancer, diabetic and cardiovascular disease. Risk of cardiac increase more in diabetic patient's hence regular blood Glucose monitoring is required. Much research is going on to develop a non-invasive blood glucose sensor. This paper highlights some of them in short and their future challenges. Table no 1 shows different biosensor and their future scopes.
Table no.1

\begin{tabular}{|c|c|c|}
\hline Type of sensor & $\begin{array}{l}\text { Working } \\
\text { principle }\end{array}$ & Future scope \\
\hline $\begin{array}{l}\text { Electrochemic } \\
\text { al biosensor }\end{array}$ & $\begin{array}{l}\text { Bio } \\
\text { electrochemi } \\
\text { cal reaction }\end{array}$ & $\begin{array}{l}\text { More research is } \\
\text { required for } \\
\text { selectivity, } \\
\text { sensitivity, range } \\
\text { and life span }\end{array}$ \\
\hline Optical sensor & $\begin{array}{l}\text { Measuremen } \\
\mathrm{t} \text { of optical } \\
\text { parameters } \\
\text { like } \\
\text { absorbance } \\
\text { and } \\
\text { Fluescrren }\end{array}$ & $\begin{array}{l}\text { Signal conversion, } \\
\text { range, and accuracy }\end{array}$ \\
\hline $\begin{array}{l}\text { Piezoelectric } \\
\text { Biosensor }\end{array}$ & $\begin{array}{l}\text { Electrostatic } \\
\text { charge } \\
\text { generation } \\
\text { with } \\
\text { Enzymes }\end{array}$ & $\begin{array}{l}\text { Stability, range, and } \\
\text { accuracy }\end{array}$ \\
\hline Immunosensor & $\begin{array}{l}\text { It is a } \\
\text { combination } \\
\text { of an } \\
\text { electrochemi } \\
\text { cal, } \\
\text { piezoelectric } \\
\text { and optical } \\
\text { sensor used } \\
\text { for analysis } \\
\text { of molecular } \\
\text { components }\end{array}$ & $\begin{array}{l}\text { Range, cost and } \\
\text { selectivity }\end{array}$ \\
\hline $\begin{array}{l}\text { Cloth based } \\
\text { capacitive } \\
\text { sensor }\end{array}$ & $\begin{array}{l}\text { Electrostatic } \\
\text { principal }\end{array}$ & $\begin{array}{l}\text { Accuracy with } \\
\text { movement is a major } \\
\text { concern }\end{array}$ \\
\hline $\begin{array}{l}\text { ECG based } \\
\text { biosensor }\end{array}$ & $\begin{array}{l}\text { Change in } \\
\text { pattern of } \\
\text { ECG signal }\end{array}$ & $\begin{array}{l}\text { Accuracy and } \\
\text { calibration }\end{array}$ \\
\hline
\end{tabular}

Above sensor technology are the future developments of the non-invasive sensor for glucose monitoring. Success in any one of the above technology can act as a best glucose monitoring tool for diabetic patient, hence have eyes on future development in sensor technology.

\section{B. Diet monitoring system}

The diabetic patient undergoes insulin administration on a daily basis. This insulin intake is used to compensate for the effect of meal carbohydrate (CHO).Calculation of the exact value of insulin intake is more complex and time-consuming factor. Under and overestimation of insulin can cause long term damage to the patients health. Accurate measurement of carbohydrate will be the basic challenge in diabetic control and prevention. Due to Artificial intelligence and mobile application, it is now possible to develop a correct tool for calculation of carbohydrate is possible. In recent years research to calculate carbohydrates contents in food is under process. The food carbohydrate calculation system can be explained by the following diagram.

Block diagram of the Artificial intelligence food 
recognition system.

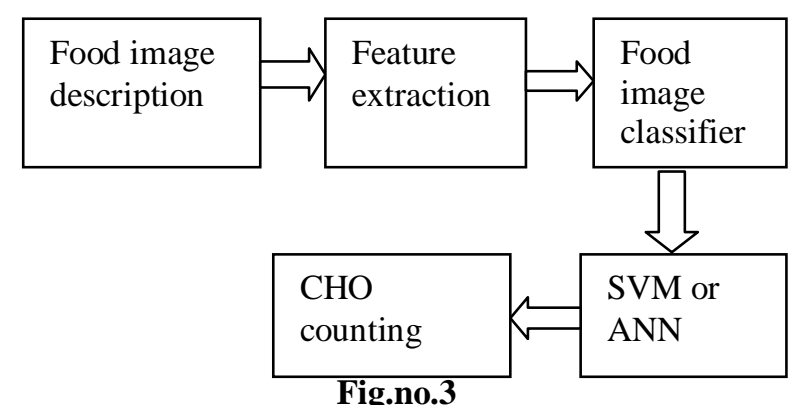

In order to develop portable mobile application more modification is required in this system to improve the accuracy which is near about $78 \%$ [13-14]. The future challenge is to generate a cost-effective, highly accurate mobile application for carbohydrate calculation which will be the revolution in the prevention of diabetic. To improve accuracy, enhancement in visual dataset and advancement in classifier algorithm is the future scope in this application.

\section{The activity monitoring system}

It is another tool for diabetic prevention where a lot of innovations have been taken place due to the use of wearable and mobile devices. Physical activity measurement basically is classified into two parts i.e. step counts and energy expenditure. In market there are many techniques commercially available to measure physical activity with classification algorithms known as Move monitor, Fit bit one, ActivPal, Niket+, fuel band, and Body Media. Normally used algorithms consists of windowed peak detection on a magnitude of triaxial, acceleration vector via low pass filtering with delay, frequency, and wavelet transformation, sensor orientation and earth's gravitational acceleration with high pass filter. The basic drawback of wearable devices for step counting is an error in measurement of accurate step counting during low and high speed. Future challenges are how to improve step count accuracy and develop activity measurement other than steps like swimming and other physical activity.

Another area where research is underdevelopment is Energy expenditure estimation which is further get classified into Resting Energy Expenditure (REE) and Activity Energy Expenditure (AEE). Both techniques work on oxygen consumption and carbon dioxide production. Basic limitation for energy expenditure

Estimation is instrument availability, logistical barriers and inability to measure specific activity effect on energy expenditure [8-12]. Wearable devices are increasing rapidly in the biomedical and commercial market hence the future goal is how to collect and process physical dataset from the environment. Following diagram shows the review idea about recent activity monitoring scenario.

Fig.no.4 shows the Basic concept of the activity monitoring system.

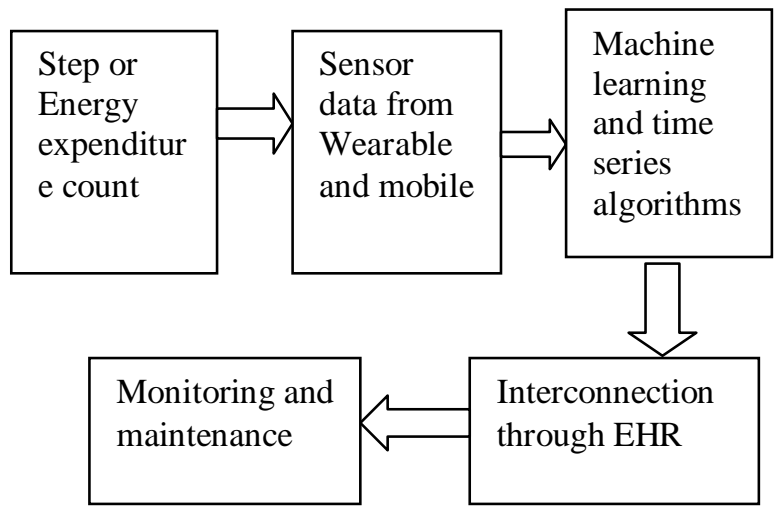

Fig.no.4

\section{Intelligence foot}

Another important area of research in diabetic management is intelligent foot ware system. This method is helpful for monitoring and prevention of foot complication such as pathological Neurology, foot ulcerations, and infection. Foot parameters consist of plantar pressure, force, velocity, acceleration, contact time, temperature, and humidity. Above all parameters are measured by foot sensors and generate useful information for foot diagnosis, and evaluation of the human physiological conditions. Machine learning algorithms and mobile devices can make big revolutions in future to generate accurate and preventive information to the patient and doctor to avoid foot complications due to diabetic. Fig.no.5 shows the basic structure of intelligent foot.

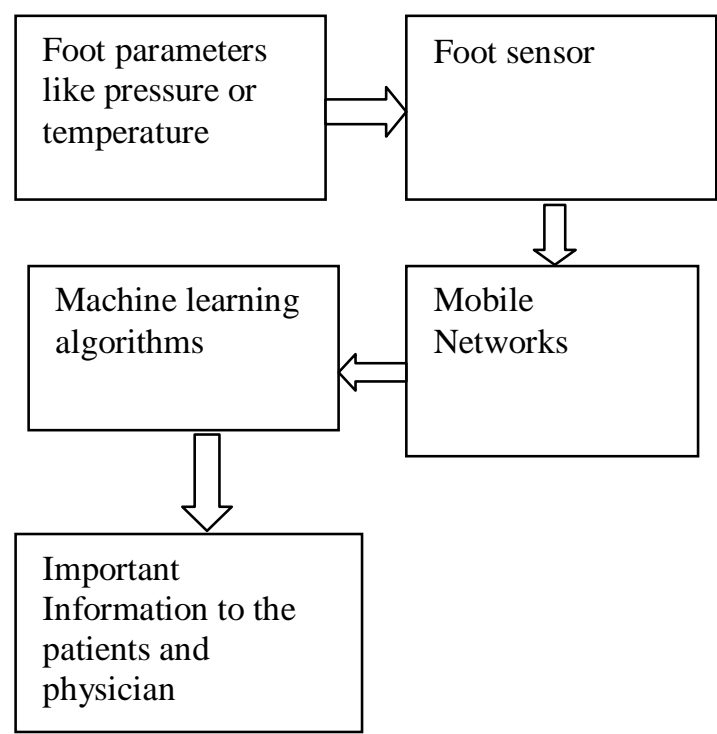

Fig.no.5

There are two commonly used foot measurement systems known as Planter pressure measurement, Platform and in-shoe system [15-17]. Basic drawbacks of these systems are data measured in the controlled condition of laboratories and hospitals are different than the real situation in daily life. Also this area is facing another problem in development of sensors which have bulky processing components and complex 
wiring of data acquisition systems. Future development is required in terms of smaller size sensors; simple wiring systems and development of artificial algorithms which will provide easy to use foot wear system to the diabetic patients.

\section{E. Artificial pancreas}

The final area of artificial intelligence in diabetic control is developing precise artificial pancreas which will manage blood glucose level. Insulin is the only one hormone which will keep glucose control in the body. Exact calculation of glucose is another important research task in front of a medical researcher. Many research options are under developments in which Bi-hormonal artificial pancreas using switching Economic predictive control model which consist of insulin subsystem and glucose subsystem can be predictively controlled by switching PID controller. Another model which is based on a nonlinear control system based on (TS) Fuzzy model which consists of an effective and exact representation of a complex nonlinear system with a compact set of variable [18-24].By the above methods successful implementation of artificial pancreas or insulin pumps depends upon exact calculations of activity monitoring, measurement of glucose, carbohydrate intake in the body. Basic structure of artificial pancreas will be explained by Figure no.6.

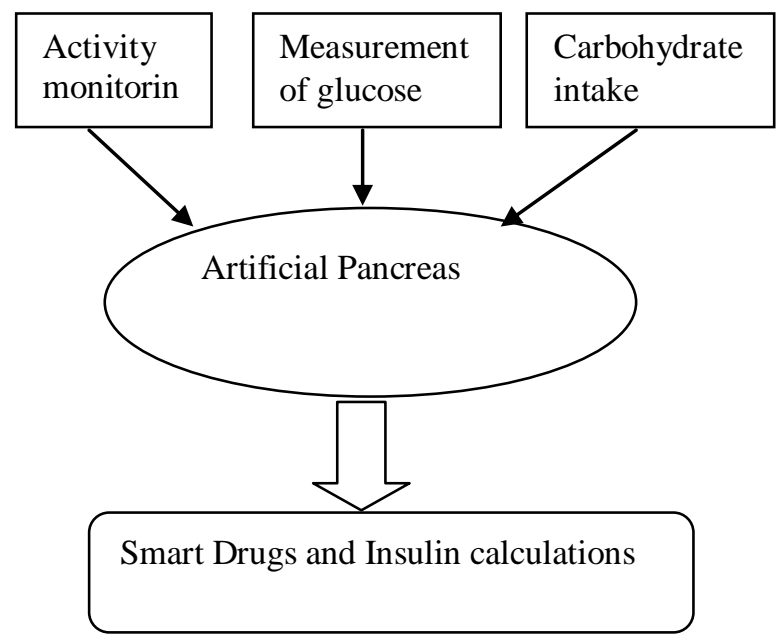

Fig.no.6

The successful design of artificial pancreas depends upon the technique used to design artificial pancreases like fuzzy logic or nonlinear control system or artificial intelligence.

\section{RECENT TRADES OF ARTIFICIAL INTELLIGENCE IN DIABETIC CARE}

Number of studies is carried out in the recent years which will signify that artificial intelligence can act as a best technical tool for diabetic care and diabetic management. First artificial intelligence application is developed to detect diabetic retinopathy which does not require a physician to interpret the images [25]. Some of the recent developments in the field of artificial intelligence in medical applications is given in table no.2.
Table no.2

\begin{tabular}{|c|c|c|}
\hline $\begin{array}{l}\text { Refe } \\
\text { renc } \\
\text { e }\end{array}$ & Recent Model & Application \\
\hline$[26]$ & $\begin{array}{l}\text { Dexcom Next } \\
\text { generation G6 } \\
\text { sensor }\end{array}$ & $\begin{array}{l}\text { For measurement blood } \\
\text { glucose }\end{array}$ \\
\hline$[27]$ & $\begin{array}{l}\text { Medtronic's } \\
\text { minimed 670G }\end{array}$ & $\begin{array}{l}\text { Artificial pancreas with } \\
\text { Gardian } 3 \text { CGM technology }\end{array}$ \\
\hline$[27]$ & Sugar.IQ & $\begin{array}{lrr}\text { Mobile } & \text { Application } & \text { to } \\
\text { analysis } & \text { treatments } & \text { in } \\
\text { diabetic } & & \\
\end{array}$ \\
\hline$[28]$ & $\begin{array}{l}\text { Bio- foot } \\
\text { Biomedical }\end{array}$ & $\begin{array}{l}\text { Uses Artificial intelligence } \\
\text { for delivery of insulin to } \\
\text { diabetic people }\end{array}$ \\
\hline [29] & DIABNEXT & $\begin{array}{l}\text { Personalized } r \\
\text { Analysis to provide a } \\
\text { decision to patient and } \\
\text { physician }\end{array}$ \\
\hline [30] & $\begin{array}{l}\text { Dreamed } \\
\text { diabetics }\end{array}$ & $\begin{array}{l}\text { Decision support system } \\
\text { increases the capability of } \\
\text { insulin dependent patients }\end{array}$ \\
\hline [31] & Hedia & $\begin{array}{l}\text { Artificial intelligence based } \\
\text { Diet, Activity monitoring } \\
\text { and selecting insulin }\end{array}$ \\
\hline [32] & Type Zero & $\begin{array}{l}\text { use next-generation data } \\
\text { transfer technology to } \\
\text { develop a specialized tool } \\
\text { for Blood Glucose } \\
\text { monitoring }\end{array}$ \\
\hline$[33]$ & XBird & $\begin{array}{l}\text { Analyze insulin data points } \\
\text { with artificial intelligence to } \\
\text { create an effective solution } \\
\text { for patients and physician }\end{array}$ \\
\hline [34] & Smart Insulin & $\begin{array}{l}\text { Australian Institute of } \\
\text { Bioengineering and } \\
\text { Nanotechnology at the } \\
\text { University of Queensland, } \\
\text { researcher Dr. Chung Xu } \\
\text { proved the concept of } \\
\text { "smart" insulin delivery on } \\
\text { mice, which provides for the } \\
\text { release of insulin with an } \\
\text { increase in blood glucose } \\
\text { level }\end{array}$ \\
\hline
\end{tabular}

\section{DISCUSSION \& RESULTS}

Digitalization of medicine is the future need of the society. Recent developments of artificial intelligence can provide better version of treatment tools for diabetic health care. Following table provides some of the important points for future development in the area of artificial intelligence and diabetic care act as a summary of this paper. 
Table no.3

\begin{tabular}{|c|c|c|}
\hline $\begin{array}{l}\text { Diabetic } \\
\text { management } \\
\text { area }\end{array}$ & $\begin{array}{l}\text { Application } \\
\text { area }\end{array}$ & Future scope \\
\hline $\begin{array}{l}\text { Sensor } \\
\text { technology }\end{array}$ & $\begin{array}{l}\text { Regular } \\
\text { measurement } \\
\text { of glucose } \\
\text { level }\end{array}$ & $\begin{array}{l}\text { Stable, Noninvasive, } \\
\text { easy to use and durable } \\
\text { sensor technology }\end{array}$ \\
\hline $\begin{array}{l}\text { Diet } \\
\text { monitoring }\end{array}$ & $\begin{array}{l}\text { Measurement } \\
\text { of } \\
\text { carbohydrate } \\
\text { content in the } \\
\text { meal }\end{array}$ & $\begin{array}{l}\text { Highly accurate food } \\
\text { recognition Artificial } \\
\text { intelligence algorithms }\end{array}$ \\
\hline $\begin{array}{l}\text { Activity } \\
\text { monitoring }\end{array}$ & $\begin{array}{l}\text { Natural } \\
\text { reduction of } \\
\text { Blood glucose } \\
\text { level }\end{array}$ & $\begin{array}{l}\text { Real-time on node } \\
\text { accurate analysis of } \\
\text { activity. }\end{array}$ \\
\hline Intelligent foot & $\begin{array}{l}\text { To monitoring } \\
\text { foot } \\
\text { complication } \\
\text { of diabetic } \\
\text { patients }\end{array}$ & $\begin{array}{l}\text { Durability, easy to use } \\
\text { and simple circuit } \\
\text { arrangement. }\end{array}$ \\
\hline $\begin{array}{l}\text { Artificial } \\
\text { Pancreas }\end{array}$ & $\begin{array}{l}\text { For the } \\
\text { prevention and } \\
\text { management } \\
\text { of glucose } \\
\text { level for } \\
\text { diabetic } \\
\text { patients }\end{array}$ & $\begin{array}{l}\text { Development } \\
\text { Artificial pancreas by } \\
\text { using nonlinear control } \\
\text { system. Fuzzy logic, } \\
\text { Deep learning } \\
\text { algorithms }\end{array}$ \\
\hline
\end{tabular}

\section{CONCLUSION}

Many applications are available in the market which will provide cost-effective mobile health to diabetic patients. But due to lack of information and accuracy of these devices, there is a potential gap between patient and mobile application. Diabetic are fourth major chronic diseases spread heavily worldwide and it is one of the costlier treatment diseases which can cause damage to the life span if proper care and self-management are not done timely. Field of mobile and artificial intelligence increases widely now days hence it is possible to provide complete E-health solution for diabetic treatment by using the combination of sensor technology, Diet monitoring, Activity monitoring, intelligent foot, and Artificial Pancreas. Successful implementation of E-health for diabetic is possible by the accurate implementation of this technology and proper education to all the patients from childhood to old age. Technology development in diabetic management can provide the best future promise to society. Complete Diabetic E-Health solution combines the effect of Activity, self-control in terms of diet and personalized help from the digital solution which is a combination of both mobile and artificial intelligence is the future of diabetic solution.

\section{REFERENCES}

1. Wang, H. C., \& Lee, A. R. (2015). Recent developments in blood glucose sensors. Journal of Food and Drug Analysis. Elsevier Taiwan LLC. https://doi.org/10.1016/j.jfda.2014.12.001

2. Musale, R., \& Paithane, A. N. (2018). Design and develop an algorithm for diabetic detection using ECG signal. In Proceedings of the International Conference on
Computing Methodologies and Communication, ICCMC 2017 (Vol. 2018-January, pp. 961-966). Institute of Electrical and Electronics Engineers Inc. https://doi.org/10.1109/ICCMC.2017.8282610.

3. Satish, Sen, K., \& Anand, S. (2017). Design of microstrip sensor for non-invasive blood glucose monitoring. In 2017 International Conference on Emerging Trends and Innovation in ICT, ICEI 2017 (pp. 5-8). Institute of Electrical and Electronics Engineers Inc https://doi.org/10.1109/ETIICT.2017.7977001

4. Castillo, J., Gáspár, S., Leth, S., Niculescu, M., Mortari, A., Bontidean, I., ... Csöregi, E. (2004, September 13). Biosensors for life quality - Design, development, and applications. Sensors and Actuators, B: Chemical.Elsevier. https://doi.org/10.1016/j.snb.2004.04.084

5. Sonawane, A., Manickam, P., \& Bhansali, S. (2017). Stability of Enzymatic Biosensors for Wearable Applications. IEEE Reviews in Biomedical Engineering. Institute of Electrical and Electronics Engineers. https://doi.org/10.1109/RBME.2017.2706661

6. Ahola, T. M. (2011). Pedometer for Running Activity Using Accelerometer Sensors on the Wrist. Medical Equipment Insights, 3, MEI.S3748 https://doi.org/10.4137/mei.s3748

7. Rachim, V. P., \& Chung, W. Y. (2019). Wearable-band type visible-near infrared optical biosensor for non-invasive blood glucose monitoring. Sensors and Actuators, B: Chemical, 286, 173-180 https://doi.org/10.1016/j.snb.2019.01.121

8. Bassett, D. R., Toth, L. P., LaMunion, S. R., \& Crouter, S. E. (2017, July 1). Step Counting: A Review of Measurement Considerations and Health-Related Applications. Sports Medicine. Springer International Publishing.

9. Ravi, D., Wong, C., Lo, B., \& Yang, G. Z. (2017). A Deep Learning Approach to on-Node Sensor Data Analytics for Mobile or Wearable Devices. IEEE Journal of Biomedical and Health Informatics, 21(1), 56-64. https://doi.org/10.1109/JBHI.2016.2633287

10. itt, D., Kellogg, R., Snyder, M., \& Dunn, J. (2019) Windows Into Human Health Through Wearables Data Analytics. Current Opinion in BiomedicalEngineering. https://doi.org/10.1016/j.cobme.2019.01.001

11. Mifflin, M. D., St Jeor, S. T., Hill, L. A., Scott, B. J. Daugherty, S. A., \& Koh, Y. O. (1990). A new predictive equation in healthy individuals for resting energy. American Journal of Clinical Nutrition, 51, 241-247.

12. Squires, R. W. (2012). Essentials of Exercise Physiology. Mayo Clinic Proceedings, 70(1), 104 https://doi.org/10.1016/s0025-6196(11)64682-x

13. Anthimopoulos, M. M., Gianola, L., Scarnato, L., Diem, P., \& Mougiakakou, S. G. (2014). A food recognition system for diabetic patients based on an optimized bag-of-features model. IEEE Journal of Biomedical and Health Informatics, 18(4), 1261-1271. https://doi.org/10.1109/JBHI.2014.2308928

14. Rizvi, A. A. (2009, April). Nutritional challenges in the elderly with diabetes. International JournalofDiabetesMellitus. https://doi.org/10.1016/j.ijdm.2009.05.002

15. Shu, L., Mai, K. Y., Tao, X. M., Li, Y., Wong, W. C., Lee, K. F., Yuen, C. P. (2012). Monitoring diabetic patients by novel intelligent footwear system. In ICCH 2012 Proceedings - International Conference on Computerized 
Healthcare (pp. 91-94). IEEE Computer Society. https://doi.org/10.1109/ICCH.2012.6724478.

16. Torres, I. A., Leija, L., Vera, A., Maldonado, H., Bayareh, R., Gutierrez, J., \& Ramos, A. (2018). Computational support system for early diagnosis of the diabetic foot. In 2018 Global Medical Engineering Physics Exchanges/Pan American Health Care Exchanges, GMEPE/PAHCE 2018 (pp. 1-5). Institute of Electrical and Electronics Engineers Inc.

https://doi.org/10.1109/GMEPE-PAHCE.2018.8400743

17. Shu, L., Mai, K. Y., Tao, X. M., Li, Y., Wong, W. C., Lee, K. F., ... Yuen, C. P. (2012). Monitoring diabetic patients by novel intelligent footwear system. In ICCH 2012 Proceedings -International Conference on Computerized Healthcare (pp. 91-94). IEEE Computer Society. https://doi.org/10.1109/ICCH.2012.6724478

18. Mainoti, G. F., \& Isabirve, N. (2018). Examining the Success Factors for Mobile Applications for SelfManagement of Diabetic Treatment in a South African Context. In 2018 Open Innovations The conference,OI 2018 (pp. 198-202). Institute of Electrical and Electronics Engineers Inc. https://doi.org/10.1109/OI.2018.8535910.

19. Kang, Z., Pan, J., Zhang, W., \& Zou, X. (2018). A T-S Fuzzy Model-Based Algorithm for Blood Glucose Control in Diabetic Patients. In Proceedings of 2018 IEEE 3rd Advanced Information Technology, Electronic, and Automation Control Conference, IAEAC 2018 (pp. 1110-1113). Institute of Electrical and Electronics EngineersInc. https://doi.org/10.1109/IAEAC.2018.8577639.

20. Shankaracharya, Odedra, D., Samanta, S., \& Vidyarthi, A. S. (2010). Computational intelligence in early diabetes diagnosis: A review. Review of Diabetic Studies. https://doi.org/10.1900/RDS.2010.7.252

21. O’Brien, R. T., Dilks, A. E., \& Lukas, D. J. (2018). Personalization of a Glucose-Insulin Model for Diabetic Patients. In Proceedings of the American Control Conference (Vol. 2018-June, pp. 2151-2156). Institute of Electrical and Electronics Engineers Inc. https://doi.org/10.23919/ACC.2018.8431057.

22. Tang, F., \& Wang, Y. (2017). Design of Bi-hormonal artificial pancreas system using switching economic model predictive control. In Chinese Control Conference, CCC (pp. 4579-4584). IEEE Computer Society. https://doi.org/10.23919/ChiCC.2017.8028078

23. Fagherazzi, G., \& Ravaud, P. (2018). Digital diabetes: Perspectives for diabetes prevention, management, and research. Diabetes and Metabolism. Elsevier Masson SAS. https://doi.org/10.1016/j.diabet.2018.08.012

24. Ashrafzadeh, S., \& Hamdy, O. (2018). Patient-Driven Diabetes Care of the Future in the Technology Era. Cell Metabolism. https://doi.org/10.1016/j.cmet.2018.09.005.

25. Neborachko, M., Pkhakadze, A., \& Vlasenko, I. (2018) Current trends of digital solutions for diabetes management. Diabetes and Metabolic Syndrome: Clinical Research and Reviews. Elsevier Ltd. https://doi.org/10.1016/j.dsx.2018.07.014

26. https://verily.com/projects/sensors/miniaturized-gcm

27. https://www.medtronicdiabetes.com/products/sugar.iq-di abetes-assistant

28. https://www.bigfootbiomedical.com/

29. https://diabnext.com/

30. http://dreamed-diabetes.com/

31. http://hedia.dk/en/frontpage/

32. http://typezero.com/

33. http://www.xbird.io/

34. https://www.diabetesqld.org.au/ 